\title{
Hřbitovní vzpoury \\ Odpor k pohřbívání sebevrahů a pojetí „nečistoty“ na českém a moravském venkově od pozdního 17. po první polovinu 19. století
}

\author{
Daniela Tinková \\ DOI: 10.21104/CL.2020.2.03 \\ Cemetery Revolts. Resistance to the Burial of Suicides and the Concept \\ of 'Impurity' in the Bohemian and Moravian Countryside from the Late \\ 17 th to the First Half of the 19th Centuries
}

\begin{abstract}
Based on selected archival materials from the Bohemian and Moravian milieus, the study deals with the problems connected to the burial of people who committed suicide. The study seeks to demonstrate the extent to which the concept of 'impurity' and 'tainting' still played a crucial role in the period in question and how it established the legitimacy of a number of 'parajudicial' practices applied to the body of a suicide (cutting off the head and limbs, burning or burial of items that came into contact with the body of the suicide or objects which the person used to kill himself/herself). These practices, usually enshrined only in custom, might be interpreted as rudiments of purifying rituals with elements of protective magic that persisted in some localities up to the 18th century, often independent of the decisions of the secular and ecclesiastical courts.
\end{abstract}

\section{Key words}

suicide, cemeteries, Czech lands, late 17th-early 19th centuries, impurity

\section{Acknowledgment}

Tato studie vznikla v rámci grantového projektu GAČR č. 17-06860S Neklidní zemřelí. Dekriminalizace, sekularizace a medikalizace dobrovolné smrti (17.-19. století), jehož nositelkou je Filozofická fakulta Univerzity Karlovy.

\section{Contact}

doc. Mgr. Daniela Tinková, PhD., Ústav českých dějin, Filozofická fakulta Univerzity Karlovy, nám. Jana Palacha 2, 11638 Praha 1, Czech Republic; e-mail: daniela.tinkova@gmail.com.

\section{Jak citovat / How to cite}

Tinková, Daniela. (2020). Hřbitovní vzpoury. Odpor k pohřbívání sebevrahů a pojetí „nečistoty“ na českém a moravském venkově od pozdního 17. po první polovinu 19. století. Český lid 107, 167-188. doi:http:// dx.doi.org/10.21104/CL.2020.2.03 
V listopadu 1761 se oběsil šedesátiletý domkář a dřevařský mistr Urban Stuttiner ${ }^{1}$ z pohraniční dřevařské vsi Zvonková - Glöckerberg, dnes již zaniklé. Ačkoli vyšlo najevo, že Stuttiner byl zbožný a slušný člověk, a navíc se mu prý poslední čtyři roky „vždycky na podzim něco spletlo v hlavě “", místní farář doporučoval uložit jeho tělo mimo hřbitov, pouze někam $\mathrm{k}$ božím mukám nebo z vnější strany hřbitovní zdi. Vrchnostenský úřad však rozhodl, že zemřelý bude pochován na hřbitově v Horní Plané, kam byla Zvonková tehdy přifařena. Rychtář Zvonkové instruoval hornoplánského faráře Antona Kitzhoffera, který souhlasil. Pohřeb měl proběhnout v noci, takže kolem desáté začal hrobník kopat na hřbitově jámu. Noční pohřeb však přišel podezřelý mládencům vracejícím se z tancovačky; vnikli na hřbitov, a když zjistili, co se děje, hrobníka napadli a ze hřbitova vyhnali. Hornoplánští, znepokojení ruchem, se začali shromaždovat kolem hřbitova a napadli i starostu. Zejména ženy prý plakaly a „pro Pána Boha" prosily, aby mezi jejich zemřelé a do blízkosti jejich domů nebyl uložen sebevrah.

Vyšetřování ukázalo, že Hornoplánští obecně dávali najevo nespokojenost, když měl být na „jejich“ hřbitově pochován někdo přespolní. A Zvonková byla navíc nově založená obec vzniklá eggenberskou kolonizací, čímž se nejspíš pocit „cizáctví a "novot“ jen posiloval. Hornoplánští argumentovali dokonce tím, že před několika lety tu farářův předchůdce pochoval jednoho utopence trpícího údajně melancholií a celé okolí pak sužovaly bouřky a nečas. ${ }^{2}$ Manželka jednoho radního se prý navíc podílela, máme-li věřit slovům faráře Kitzhoffera, na provádění „pověrečných čar" (aberglauberische Hexereyen) s mrtvým tělem. Když si farář Kitzhoffer na jednání Hornoplánských stěžoval vrchnosti, ${ }^{3}$ odsoudil v prvé řadě surovosti, neposlušnost i (doslova) pověrčivost Hornoplánských.

Kromě toho však farář zcela jednoznačně zdůraznil skutečnost, že Stuttiner byl dobrý katolík, který žil př́íkladným křestanským životem. „Kdyby takto př́kladně žili ti, kteří mu odpírají křestanský pohřeb!" dodal moralistně. Proto sám neměl proti tichému pohřbu do posvěcené půdy žádných námitek. Zaštitoval se i citátem ze sv. Augustina, který byl uživán $\mathrm{v}$ pohřebních kázáních, non potest male mori qui bene vixerit, in odiosis semper favorabilia amplectenda - kdo dobře žil, nemůže zemř́t špatně (resp. přesný citát: Mala mors putanda non est, quand bona vita praecesserit - Augustinus ed. 1979: 27-29). „Špatná“ smrt tak podle něj mohla být pouze

1 SOA Třeboň, pobočka Český Krumlov, VS Český Krumlov, I $6 \mathrm{C} \alpha$, fascikl 9, č. 25, Urban Stuttiner, rychta Glöckelberg (Zvonková), listopad 1761.

2 Šlo zjevně o př́pad Franze Schattauera: SOA Třeboň, pobočka Český Krumlov, VS Český Krumlov, I 6 C $\alpha$, fascikl 9, č. 18. Horní Planá, 1747.

3 Př́pad Urbana Stuttinera cit. 
důsledkem špatného života, proto doporučoval předpokládat nevinu a dovolával se Božího soudu, který jediný může rozhodovat. Faráři bylo navíc známo, že nedávno se stal podobný případ v Oticích (zaniklá obec $\mathrm{v}$ prostoru výcvikového prostoru Boletice). Tehdy byl prý totiž pochován takto na hřbitově u zdi dokonce luterán zabitý v souboji, a to zcela bez jakéhokoli odporu ze strany obce, takže hornoplánský farář usoudil, že „když se můžou bez odporu pochovávat kaciŕi, tím spíš si takové místo zaslouží zbožný katolický křestan“. „Nikdo navíc nemůže vědět, jaký soud mu připraví velký Bůh“, pokračoval rozvážně. „V hlavě se může kdeco pomotat (...) Lidé se mají bát pouze Boha, ne nějakých zlých duchů (böse Geister). Kéž by sami dokázali následovat takový př́íkladný a zbožný život, jaký vedl tento zesnulý domkár̆!“ Dopis hornoplánského faráře je nanejvýš pozoruhodný. Málokdy, navíc ještě v polovině 18. století, prosadil duchovní na vlastní odpovědnost pohřeb sebevraha do posvěcené půdy a hájil jej s takovou vervou, navíc s argumentací čistě křestanskou.

"Hřbitovní vzpoury" kvůli pohřbům sebevrahů se odehrávaly zjevně v celé raně novověké a novověké Evropě. Co o nich víme a co nám vypovídají o smýšlení a cítění venkovských obyvatel? Cílem této studie je poukázat na základě vybraných archivních materiálů z období od konce 17. do první poloviny 19. století na kolektivní postoje venkovské komunity $\mathrm{k}$ tělům sebevrahů a zasadit tyto postoje do širš́ho kontextu vnímání "nečistého“. Proměny postihu sebevraždy a její dekriminalizace se staly zejména $\mathrm{v}$ posledních desetiletích předmětem zájmu řady evropských sociálních i kulturních historiků a historiček (srov. např. Schär 1985; MacDonald - Murphy 1990; Lederer 1994; Koslofsky 1997; 1999; 2004; Lind 1999; Watt 2001; Kästner 2011; Murray 2009; Luef 2010; 2016). Také $\mathrm{v}$ našem prostředí již toto téma začalo být studováno, proto k obecnějšímu kontextu odkážeme na starší i soudobé bádání (zejm. Tinková 2004; 2018a; 2018b; 2019; Pátková 2014; Liepoldová 2018; 2019; Lipovský 2018) i k výzkumům etnografickým (zčásti např. Navrátilová 1996; 2004). Omezíme se tu tedy jen na to nejdůležitější pro kontext studovaného tématu.

Již během středověku se zjevně ustálila praxe, fixovaná zpravidla od 16. století pozitivním - trestním - právem, že „usvědčený“ sebevrah podléhal v zásadě „trojímu“ trestu: 1) v části Evropy stihla jeho jmění peněžitá újma či prímo konfiskace; 2) v souladu se zásadami kanonického práva mu byly odepřen církevní pohřeb, spočinutí v posvěcené půdě, ale i zádušní mše a modlitby. Ty byly ostatně podle některých teologů zbytečné, nebot taková duše byla beztak odsouzena $\mathrm{k}$ věčnému zatracení. ${ }^{4}$

4 Hlubší teologické zakotvení tématu by zde jistě bylo žádoucí, přesahuje však rozsahové možnosti předložené studie; otázka sebezabití v teologickém pojetí s ohledem na raně novověké období byla nicméně nově pojednána - Malý 2018. 
Zjevně po celé Evropě bylo sebevrahovo bezduché tělo vystaveno celému komplexu zneuctujících potupných praktik. Tyto „tělesné tresty" se podle některých autorů začaly uplatňovat později než konfiskace. Jejich nárůst a akcentovaná př́snost byly údajně charakteristické pro období 16. a raného 17. století (srov. např. Houston 2010; Lind 1999; Lederer 1994; Murray 2009; Vandekerckhove 2001; Spierenburg 1984). Je otázkou, zda se podobné praktiky skutečně začaly uplatňovat až $\mathrm{v}$ raně novověkém období, anebo byly pouze v této době „legalizovány“ pozitivním trestním právem, tj. zda nezískaly legitimitu starší zvyky, jež mohly původně představovat formu odlučovacího rituálu s prvky ochranné magie: formy vynášení sebevraha $\mathrm{z}$ domu bývají převrácenou formou vynášení standardního nebožtíka; různé formy likvidace či mrzačení těla upomínají spíše na rituály očisty (spálení) či ochranu proti vampýrům (utětí hlavy, probodnutí těla). Jde o způsoby zacházení s mrtvým tělem sebevrahů a jejich věcmi, o praktiky, které nejsou zakotveny ani v právu trestním, ani kanonickém, proto jsou některými autory (MacDonald Murphy 1990) označovány za „parajudiciální“. Představují spíše jakousi "doplňkovou“ či „dobrovolnou“ součást trestu vyneseného prŕslušnou soudní instancí, nicméně v místní komunitě hrají velmi významnou roli. Dá se předpokládat, že šlo svým způsobem o formy odlučovacího či očistného rituálu s prvky ochranné magie aplikované na „nečisté“ zemřelé. Pro nás jsou tak právě dokladem o vnímání těla jako „nečistého“. Sebevrazi zkrátka náleželi k těm „neklidným zemřelým“, „pomezním bytostem“ (termínem angloamerické kulturní antropologie liminary beings), které nedokončily svůj přechodový/odlučovací rituál a musely bloudit mezi světem mrtvých a světem živých (srov. např. van Gennep 1997: 149; Sumner 1906; 103). Jejich občasné návraty mezi živé vzbuzovaly neklid a strach, což evidentně posilovalo potřebu zmíněných „parajudiciálních" praktik.

V každém př́padě však platila zásada, že odsoudit jako sebe-vraha za samo-vraždu - felo de se, Selbstentleibung - lze pouze toho, kdo se svého činu dopustil s plným vědomím, což vylučovalo osoby stižené šílenstvím, melancholií či jinou duševní poruchou: tu však bylo zapotřebí dokázat svědectvím sousedů a rodinných př́slušníků. Ohledy se nicméně nebraly na ty, kdo se zahubili „z bezbožného zoufalství“, jež bylo vnímáno jako selhání ve víre či přímo jako podlehnutí dábelským svodům (srov. např. Schär 1985; MacDonald - Murphy 1990; Lind 1999; Watt 2001; Kästner 2011; Tinková 2018a; 2018b; 2019).

Rozlišovalo „lidovéc prostředí takové sebevrahy „usvědčené“ a „nevinné“? Do jaké míry byl koncept (ne)čistoty vázán na úřední postupy a výsledky vyšetřování obviněných? 
V českých zemích předosvícenského období se s výslovnou kriminalizací sebevraždy setkáváme ve třech zákonících - u Koldína, v Josefině a v Theresianě. Zatímco u Koldína ještě najdeme trest spálení na popravišti, počínaje Josefinou se již hovoří jen o zakopání katem na mrchovišti; jsou ovšem připuštěny i další „lokální obyčeje“ - tedy již zmíněné „parajudiciální praktiky“. V česko-rakouských zemích habsburské monarchie můžeme sledovat tři fáze dekriminalizace: 1) zrušení potupného zacházení a všech „parajudiciálních praktik“ za Josefa II. (1787), 2) rekvalifikace zločinu sebevraždy na pouhý policejní přestupek za Františka I. (1803/1804), 3) dekriminalizace sebevraždy (1850) a posléze i automatické přijetí sebevrahů do posvěcené půdy hřbitova (1873), byt' zpravidla bez slavnostního obřadu.

Na studovaných případech ze staršího období, geograficky převážně z Krumlovska a dalších jihočeských domén, můžeme vidět, že přinejmenším $\mathrm{v}$ tomto regionu se již $\mathrm{v}$ posledních desetiletích 17. a na prahu 18. století neuplatňoval plný rozsah represivního arzenálu. U „usvědčených" sebevrahů se v té době většinou volilo zakopání na neposvěceném místě, zpravidla $\mathrm{v}$ lese, a to bud' katem (u závažnějších př́ípadů, kdy byl zemřelý shledán skutečně „nečistým"), nebo hrobníkem. Jen velmi zř́dka bylo nařízeno spálení, zakotvené v trestním zákoníku: uplatňovalo se vlastně jen u osob žijících na okraji (žebráci), o které nejevili zájem př́buzní. Pouze v několika málo př́ípadech máme doloženy parajudiciální mrzačící praktiky - utínání hlavy nebo údů; je však otázkou, zda jindy skutečně nebyly uplatňovány, nebo pouze nedošlo $\mathrm{k}$ jejich zaznamenání. Výjimku představuje př́pad ze schwarzenberských Postoloprt, kde byly ještě v roce 1720 sebezabité Anně Šíchové odtaty dokonce všechny údy. ${ }^{5}$ Toto však každopádně představuje zatím naprosto výjimečné rozhodnutí, které možná můžeme připisovat spíše lokálním specifikům (severozápadní horský region), které však dosud nejsou obyčejově př́liš prozkoumány. $\mathrm{K}$ podobným dokladům patř́ záznam z Chrastavy na Liberecku z počátku 18. století (1707), kdy měla být oběšená žena z Andělské hory odvezena pod šibenici, kde jí měl kat před zahrabáním oddělit hlavu od těla rýčem (Svobodová 1995: 21). Na Krumlovsku tak bylo jednou zmíněno utětí hlavy (1679). ${ }^{6} \mathrm{Je}$ otázkou, zda skutečnost, že byly zneuctujuící či „očistné" praktiky v protokolech výslovně zmíněny, znamená, že šlo o výjimku, nebo bylo naopak výjimkou toto zaznamenání, nebot' se jednalo jinak o běžnou praxi, která za zmínku nestála.

5 SOA Třeboň, pobočka Český Krumlov, fond Ústřední kancelář, starší oddělení - Postoloprty. B 5 Bc 2a. Případ Anny Šíchové (1720).

6 SOA Třeboň, pobočka Český Krumlov, VS Český Krumlov, signatura I 6 C $\alpha$, fascikl 8, č. 7, prŕpad Melchiora Draschka od rychty Želnava (1679). 
Je také patrné, že v průběhu 18. století se stále rozšiřovalo „sémantické pole“ pojetí šílenství či melancholie: zatímco kolem roku 1700 bývali zbaveni viny většinou jen ti, u nichž byla svědectvími doložena nějaká forma pominutí smyslů, zatímco různé podoby „malomyslnosti“ (o zoufalství nemluvě) byly spíše interpretovány jako „zoufalství“ (tudíž zůstávaly trestně postižitelné), kolem poloviny století se již malomyslnost stále více sbližovala s „melancholií“ sousedící se „šílenstvím“ a umožňující zbavení viny.

Zastavme se nyní u zvláštních praktik, které doprovázely některé rozsudky nad sebevrahy.

\section{„Parajudiciální“ praktiky a odlučovací, „očistné“ rituály}

Občas docházelo i ke zničení („pošpiněného“) objektu, který přišel do kontaktu se sebevrahovým tělem. To se týkalo zejména oběšencova provazu, kterého se směl také dotýkat pouze kat, anebo káry, na níž bylo tělo zemřelého vezeno (Zedler 1721: 1595). Kat si směl ostatně jako součást odměny ponechávat sebevrahovy věci, jež bylo možno výhodně zpeněžit mezi venkovskou komunitou, která je vnímala jako prostředky ochranné či plodivé magie. Ještě počátkem 19. století si prý benátecký ras schoval veškeré oděvy oběšence právě $\mathrm{s}$ cílem je následně prodat (Šimeček 1912). Sebevrahovo tělo má tak, „ottovsky“ či „durkheimovsky“ řečeno, numinózní, dvojí podstatu. Stejně jako předměty posvátné mohou působit blahodárně na ty, kdo jsou povoláni k tomu s nimi zacházet, a současně škodit těm, kdo jsou vázáni zákazem (všechny formy profanací, svatokrádeží apod.; Otto 1917), tak i předměty „nečisté" mohou mít čarovnou moc, sloužit určité formě magie ve prospěch toho, kdo s nimi umí zacházet. „Lidové" prostředí tak znalo celou řadu magických praktik, které se týkaly sebevrahova těla nebo věcí (př. Koštál 1914). Zvláštní formu úkonů spíše očistného charakteru tak představuje i likvidace objektů, které sebevrahovi sloužily $\mathrm{k}$ usmrcení a přišly do bezprostředního kontaktu $\mathrm{s}$ tělem zemřelého. $\mathrm{V}$ pramenech se ještě na konci 17 . století setkáme např́klad s př́pady odtětí stromu, na němž se někdo oběsil - takový rozsudek známe např́klad z Krumlovska (1681) 7 či z Velké Bíteše (1797; Černá kniha 1979: 83). Někdy se likvidovalo i instrumentárium, které sebevrahovi sloužilo $\mathrm{k}$ odnětí života: $\mathrm{v}$ jihočeských archiválíích jsem našla několik takových př́ípadů ještě z 18. století. V březnu roku 1743 bylo nařízeno „sejmout a spálit (...) pověrečné věci“ (aberglauberische Sachen) ze stromu,

7 SOA Třeboň, pobočka Český Krumlov, VS Český Krumlov, signatura I 6 C $\alpha$, fascikl 8, č. 8, př́pad mladičkého Jakoba Stadla z Haberles/Ovesné, rychta Chroboly (1681). (Za identifikaci lokality děkuji P. Himlovi.) 
na němž se oběsila padesátiletá Justina Gallischkin od Chrobol. Byla pochována na hřbitově, takže ani v tomto př́padě nešlo o „nečistou“ zemřelou v pravém slova smyslu. ${ }^{8} \mathrm{O}$ dva roky později bylo podobně nařízeno spálit slámu a veškeré povlečení na postel a především pak staré prostěradlo, na němž se v zárí 1745 oběsila sedmdesátiletá vdova Maria Anna Borovská; pouze jehla měla být vrácena panu faráři (zjevně se očekávalo, že duchovní osoba ji nezneužije $\mathrm{k}$ „pověrečným“ účelům). ${ }^{9}$ Podobný prŕklad se ostatně dochoval ještě z roku 1755 z panství Hluboká, kde bylo nařízeno spálení dřevěného okapu, na němž se oběsil jistý Adalbert Szulkopf. ${ }^{10}$ Ani zde nešlo o „usvědčeného" sebevraha - Szulkopf byl prohlášen za slabomyslného (Blödsinnigkeit - dementia) a byl pochován v koutě hřbitova.

Další pozoruhodnou ritualizovanou formu zacházení s tělem představuje i samotné „snímání“, vyzvednutí, odnesení, popřípadě (u oběšených) odříznutí nečistého sebevrahova těla. $\mathrm{V}$ našich zemích se nejpozději $\mathrm{v}$ raném novověku musel této činnosti zpravidla ujmout kat, popř́padě ras či hrobník, tedy osoby, jež byly $\mathrm{v}$ předmoderní společnosti považovány rovněž za „nečisté“ (např. Dülmen 2003; Frank 1994: 152-158). Na základě našich výzkumů $\mathrm{v}$ jihočeských archivech se zdá, že ještě kolem roku 1700 bylo běžné, že se tělo až do úplného uzavření procesu ponechávalo na místě, kde bylo nalezeno (pověšeno). Odnášelo (a snímalo) se teprve ve chvíli, kdy bylo jasné, zda je sebevrah usvědčen, či omilostněn. Bylo to důležité i proto, aby bylo zřejmé, zda onen akt snětí/odříznutí má vykonat kat či ras, eventuálně jiná nečistá osoba, nebo člověk počestný. V souladu $\mathrm{s}$ touto racionalitou mohlo být tudíž mrtvé tělo odneseno z místa svého skonu až na základě potvrzené či vyvrácené „viny“ - typicky odříznuto v př́padě nejčastější formy sebezabití, totiž oběšení. Šlo o velmi důležitý akt: pokud se vina „potvrdila“ a sebevrah byl „usvědčen“, tělo bylo „úřredně deklarováno" jako nečisté, a tedy sprovozeno ze světa osobou rovněž nečistou. Pokud by tedy prŕbuzní odřízli sebevraha později skutečně „odsouzeného“, byli by považováni za „nepočestné“, jejich čest nenávratně poškozena, pošpiněna. Proto se také mnozí zdráhali poskytnout umírajícímu pomoc. Př́pady mrtvých, kteř́ zůstali viset na místě, kde se zabili, nebo které nikdo nevytáhl z vody, protože se bál poskvrnění cti, „nečistého doteku“, známe z různých prostředí včetně protestantského (např. Frank 1994: 171-172). Tělo zemřelé/ho tak po celou dobu vyšetřování (což

8 SOA Třeboň, pobočka Český Krumlov, VS Český Krumlov, signatura I 6 C $\alpha$, fascikl 9, č. 14, př́pad Justiny Gallischkin, rychta Chroboly (1743).

9 SOA Třeboň, pobočka Český Krumlov, Velkostatek Český Krumlov, I 6 C $\alpha$, fascikl 9, č. 17, případ Marie Anny Borovské, rychta Jamles (Jamné), zář́i 1735.

10 SOA Třeboň, pobočka Český Krumlov, Ústřední kancelář, st. O. Hluboká, sign. B 5 BC et 5 BP 2a, př́ipad Adalberta Szulkopfa (1755). 
zpravidla trvá několik dní, někdy se však proces může táhnout i týdny) spočívalo na místě skonu - visí na půdě, na stromě. Pokud byl zemřelý naopak viny „zproštěn“, mohl být odnesen či sňat osobou počestnou, což se obvykle v protokolech obzvláště zdůrazňuje a často se také připomíná, že se takové osobě nesmí dít žádná újma na cti. Takového „počestného“ sebezabitého snímá zpravidla hrobník, v průběhu 18. století se však stále častěji této činnosti ujímá nejbližší rodina.

Zajímavý byl případ čtyřicetiletého Christopha Stüftera, který se roku 1693 oběsil v Německé Maňavě (Teutschhaidl, Deutsch Haidl) u Horní Plané. ${ }^{11}$ Přestože byl prohlášen za duševně pomateného, a tudíž zbaven viny na „úmyslné sebevraždě“, hrobník odmítl jeho tělo sejmout s tím, že jeho - hrobníkův - vlastní syn byl přijat do cechu a jeho čest by došla újmy. Nepomohl ani rozkaz přímo z knížecí eggenberské kanceláře. $\mathrm{O}$ „moci“ knížecího listu, respektive přinejmenším o jeho svrchovanosti nad obecně vládnoucím „veřejným (lidovým) míněním“, měl hrobník zjevně oprávněné pochybnosti. Zproštujícímu účinku sebevrahovy „neviny" evidentně nedůvěroval a fyzický kontakt $s$ jeho tělem považoval tak jako tak za ohrožující pro čest celé rodiny. I z tohoto př́kladu je zjevné, do jaké míry převažoval „folklórní koncept" nečistoty nad právní i kanonickou definicí „provinění“. Stüfterovo tělo musela nakonec sejmout jeho žena za pomoci čtrnáctiletého syna a hrobník si od vrchnosti vysloužil napomenutí.

Nicméně v průběhu 18. století dochází postupně stále častěji k sejmutí či odnesení zemřelé/ho ještě před dokončením procesu - snad i v souvislosti se širíícími se teoriemi "mefitického vzduchu“ a u vědomí jednoduchých sanitárních pravidel. Od poloviny století není výjimkou, že už přivolaný ranhojič nebo úřední osoba (purkmistr), která má zahájit vyšetřování, nachází tělo již uložené mimo původní místo skonu; v př́padě oběšení bývá zemřelý již odříznut. $V$ té době již tělo odřízne, popř́padě i odnese, zpravidla ta osoba, která je našla, popř́padě někdo blízký. Později se tohoto aktu často ujímá právě ranhojič. Tento drobný detail možná vypovídá mimo jiné i o skutečnosti, že fyzický kontakt se sebevrahem přestává být vnímán jako nevyhnutelně zneuctujúící a pošpiňující. Současně se stále častěji dozvídáme, že se ranhojič, popř́padě i př́tomný laik, někdy pokoušejí o oživovací pokusy, což je rovněž „osvícenská novinka“: (po)vědomí o „první pomoci“ se zhruba od sedmdesátých let 18. století začalo šiřit zjevně právě v souvislosti s pokusy o oživování tzv. zdánlivě zemřelých (Červeňanská 1973; Tinková 2012: 172-179; Grubhoffer 2018).

11 SOA Třeboň, pobočka Český Krumlov, VS Český Krumlov, signatura I 6 C $\alpha$, fascikl 8, č. 15 - Christoph Stüfter, (Německá) Maňava (Teutschhaindl, Deutsch Haidl), 1693. 
Přesto uvedené př́́klady dokazují, že ani prohlášení za „nevinného“ $\mathrm{z}$ důvodu duševní nemoci, které opravňovalo $\mathrm{k}$ pochování na hřbitově, nutně nesnímalo ze zemřelého v obecném povědomí „poskvrnu“ a konotaci s „nečistým“. Bude tomu podobně právě i u „hřbitovních vzpour", kde se rovněž projevoval stejný odpor u sebevrahů „usvědčených“ $\mathrm{i}$ „melancholických". V lidovém prostřredí dlouho přetrvávala představa, že když bude sebevrah pochován na hřbitově, uhodí do kostelní věže či do nejbližšího domu blesk nebo že takový čin přivolá na celou obec krupobití (Navrátilová 2004: 316).

\section{Vzpoury na hřbitově: nečistá těla v posvěcené půdě}

Obecně se předpokládá, že strach z duše sebevraha, která se mohla vracet, aby škodila lidem, dobytku i úrodě, strach z toho, že by sebevrah přivolal na místní komunitu neštěstí v podobě špatného počasí i neúrody, se zjevně projevoval v mnoha evropských zemích. Podle některých autorů šlo o relikt z předkřestanských germánských časů, později přetvořený v lidové představivosti v ideu Božího trestu nebo naopak dábelského konání. Každopádně proti této formě strachu, která neměla vůbec nic společného $\mathrm{s}$ křestanskou vírou, se již v raném novověku vymezovaly jak duchovní, tak i světské vrchnosti a považovaly ji za „pověru“. Dostávaly se tak často do konfliktu s lokální komunitou, která v podstatě nerozlišovala ani mezi "melancholickým“ a „zlovolným" sebevrahem a odmítala oba (Schär 1985: 67; Lederer 1994: 205; Schmidt-Kohberg 2003: 145-147). Stejný odpor mohlo budit pohřbení do posvátné půdy hřbitova, stejně jako do půdy profánní - v lese či na kraji polí.

Podívejme se tedy nejprve na dva príklady odporu proti „profánním“ pohřbům do půdy neposvěcené, které najdeme na Krumlovsku v osmdesátých a devadesátých letech 17 . století. Když se v červnu roku 1683 oběsil u Horní Hraničné čtyřiašedesátiletý pacholek Georg Schöringer, ${ }^{12}$ rychta v Rychnově rozhodla, aby byl zakopán popravčím mimo hřbitov, protože u něj nebyly shledány žádné stopy duševní nemoci. Jenže když se ho kat snažil zahrabat kdesi poblíž polí, lidé (slovy vrchnosti v rozhořčené zprávě) „plní pověry“ se bouřili, že bude škodit úrodě. Kata prosili, aby ho odvlekl hlouběji do lesa, za což si dotyčný vyžádal navýšení odměny. Druhým př́ípadem byl již zmíněný př́ípad Christopha Stüftera z Německé Maňavy, který byl, na rozdíl od Schöringera, prohlášen za duševně narušeného, a tudíž „nevinného“; přesto jej odmítal i hrobník odříznout. Pro-

12 SOA Třeboň, pobočka Český Krumlov, VS Český Krumlov, signatura I 6 C $\alpha$, fascikl 8, č. 11, Horní Hraničná/Ober Martschlag, soud Rychnov. Př́pad Georga Schöringera, 1689. 
blém však byl i s jeho pohřbem. Bylo rozhodnuto, že tělo může spočinout ve vší tichosti a bez průvodu a okázalostí bud' přímo u zdi hřbitova, nebo kousek ode vsi na farní pastvině, ba dokonce že na místě mohou být vztyčena „boží muka“ nebo tam př́buzní mohou umístit kámen „pro memoria“. Jenže místní obyvatelé začali nař́kat, že by se báli tudy večer chodit „kvůli př́zrakům“ (wegen Gespenster), proto se představení obce obrátili znovu na knížete Eggenberka se žádostí o povolení pochování Stüfterova těla „na půl míle cesty“ od obce.

Opět zde vidíme, že ani „úřední zbavení viny“ nesnímalo ze sebevraha poskvrnu, kterou mohl způsobit celé komunitě. Proto se nezř́dka setkáváme s odporem vůči pochovávání i „melancholických“, tedy „nevinných“, „čistých" sebezabitých. Zejména pokud měli spočinout na hřbitově: takový nebožtík byl vnímán jako poskvrna na posvátném místě a urážka pochovaných počestných zemřelých (př. Lederer 1994: 195). Také v našich materiálech byla dokumentována řada takových př́padů, kdy se místní komunita proti pochování sebezabité osoby vzbouřila a někdy si i vynutila zakopání nežádoucího těla na jiném hřbitově, popř́padě i zcela mimo něj. Uved'me zde jen př́ípady nejzajímavějš́í.

Poměrně detailně dokumentovaný je pozdějšsi př́pad Doroty Rychtař́kové z Údraže u Vodňan,$^{13}$ která se oběsila v roce 1723 v lese. Díky svědectvím při vyšetřování převládl konsensus, že její dobrovolný odchod nezpůsobila žádná desperatio, ale Melancolei. $\mathrm{Z}$ toho důvodu neměla být pohřbena nečestně, ale počestnými lidmi, tajně, v noci, bez ceremonie, prĩvodu a zpě̃vu, a to na hřbitově nebo u hřbitovní zdi. Jenže rychtář s farářem odmítli sebevražednici na hřbitov přijmout, takže otec a manžel ji nakonec museli zakopat na vzdáleném, někdejším morovém hřbitově z dob epidemie z roku 1679-1680.

Osvícenské diskuse zpochybnily smysluplnost postihu sebevraždy a některé země, Prusko, Toskánsko a revoluční Francie, ji skutečně dekriminalizovaly. V josefínském trestním zákoníku z roku 1787 sice sebevražda zločinem zůstala a „usvědčený“ sebevrah měl být zakopán mimo hřbitov, byly však zakázány všechny dodatečné zvykové praktiky a zakopání těla měl provádět pohodný, nikoli již kat [po (dočasném) zrušení trestu smrti Josefem II. kat beztak ztratil svůj raison d'être]. $Z$ devadesátých let 18. století, kdy platil josefínský trestní zákoník, máme z krumlovského panství dva pozoruhodné př́pady, které skončily zakopáním na neposvěceném místě mimo hřbitov. Pozoruhodné proto, že měly trochu paradoxně takové vyústění navzdory skutečnosti, že soud původně spočinutí na hřbitově povolil.

13 SOA Třeboň, pobočka Třeboň, VS Protivín, karton 231, V BC 4a/2, případ Doroty Rychtař́kové z Údraže (1723). 
První se odehrál v roce 1794. Magdaléna Klimešová, ${ }^{14}$ mladá chalupníkova žena z Jaronína, malé obce jihovýchodně od Prachatic, se oběsila 19. září 1794. Protože se prokázalo, že se v poslední době chovala zmateně, kriminální soud v Českých Budějovicích, v souladu s prvoinstančním soudem vrchnostenským $\mathrm{v}$ Krumlově, nařídil pohřeb na hřbitově v nedalekém Brlohu, byt' „stranou“ a pochopitelně „bez obvyklé okázalosti“. Pohřeb ale zmařil postoj brložské obce. Místní farář nakázal hrobníkovi vykopat Magdaleně hrob za hřbitovní zdí a kolem kritického místa se shromáždili místní, kteří začali hrobníkovi vyhrožovat násilnostmi. Tehdy zasáhl evidentně justiciár ${ }^{15}$ a snažil se zjednat klid a přimět nespokojence, aby pohřeb umožnili. Když však viděl, že jejich odpor nezdolá, rozhodl se "ponechat je jejich pověrám“ a najít pro Magdalénu jiné místo. A protože se $\mathrm{k}$ nim přidali i dalš́ farníci z přifařených obcí, nakonec bylo rozhodnuto ostatky neštastnice odnést do lesa. Jenže ani tam nebyl nikdo z jaronínské obce, dokonce ani za úplatu a s pohrůžkami, ochoten podílet se na vykopání hrobu. Do hloubení jámy se nakonec musel pustit sám komisař s johannesthalským rychtářem, jakkoli rychtářův zet' lamentoval, že tohle místo bude přitahovat hromy a blesky i všechna neštěstí, která jistě postihnou přilehlá pole. Několik dní po zakopání těla se krajem začaly šiřit fámy, že se místní sedláci obávají o své sklářské boudy ležící ve stejném lese jako nebožka, a zjevně se pokusí tělo vykopat - „k posílení své pověry“. Krumlovský justiciár Franz Watzl tehdy pohrozil rebelům likvidací zmíněných sklářských bud a rozhořčeně komentoval: „Jen takovým způsobem budou pověry, tak silné $\mathrm{v}$ tomto kraji a u tohoto lidu, konečně vykořeněny“, povzdechl si Watzl na závěr svého listu. „U tohoto lidu,“ dodal, „který je tak spokojen se svými zlořády.“V matrice je u Magdalény Klimešové uvedeno, že ji měl pochovat kaplan s povolením kriminálního soudu, ale že to „nebylo príijato lidem“ (non admissum a populo) ${ }^{16}$

Ještě dramatičtější situace nastala o dva roky později, v únoru 1796, když se na půdě u svého mistra oběsil mladý krejčovský učeň, selský synek z Prášil, Martin Hoffmann. Protože vyšetřování prokázala, že trpěl dlouhodobě malomyslností, bylo shrnuto, že svůj čin mohl spáchat jedině ve stavu bludů a halucinací. Mladíkovi byl tudíž povolen pohřeb na hřbitově v Habikau (snad Habichau - Jestř́bí), ovšem pouze na odlehlém místě, bez prưvodu a okázalostí. Jenže hornoplánský farář Karl Holzinger,

14 SOA Třeboň, pobočka Český Krumlov, VS Český Krumlov sign. II B 5 BC 3 (I) Př́pad Magdaleny Klimeschové Jaronín, gericht Johannesthal, 1794.

15 Správce panství, od josefínské doby povinně školený a zčásti placený státem.

16 Digitální archiv SOA Třeboň, Sbírka matrik jihočeského kraje, sídlo FÚ: Brloh, kniha 5, Z 1767-1800, s./fol. 21, snímek č. 307. Za laskavé vyhledání děkuji Josefu Vackovi. 
který zjevně obhospodařoval i tamní hřbitov, se postavil proti a rodině sdělil, aby si našla jiné místo. Také „obyvatelé Černé se dali slyšet, že takové tělo zde rozhodně nechtějí trpět, a to ani mimo hřbitov, natož na něm“. Rodina tedy zvolila pohřeb na vlastním pozemku, i to však zjevně budilo nevoli. Rozhořčený list z krumlovské kanceláře pro krajský soud, pravděpodobně opět z pera justiciára Watzla, se netajil odsudkem takových „předsudkü“, tím spíš, že obecný lid popichuje farár̆, který měl naopak dávat své křestanské smýšlení najevo tím, že se bude u lidu snažit takové pověry vykořenit, jinak můžeme očekávat jen ty nejnepř́ijemnější následky. Žádal budějovický krajský soud, aby povolil přenos těla z původního místa na hřbitov, samozřejmě za noci a v tichosti, aby tato exhumace a nové uložení nebudily pozornost. Odpověd' z Budějovic však musela Watzla překvapit: krajský soud důsledně nabádal $\mathrm{k}$ tomu, aby bylo tělo ponecháno tam, kde je, jelikož obec by se mohla postavit proti, což by mohlo přivodit "neblahé následky“ ${ }^{17}$

Jde o jeden z mála př́padů, kdy se krajský soud staví k takové záležitosti př́sněji než nižší instance. Jde evidentně o pragmatické rozhodnutí: precedens Magdalény Klimešové ukázal, že taková exhumace sebezabité/ ho navzdory odmítnutí místní komunity v sobě nese velký konfliktní potenciál, a krajský soud tak upřednostnil zájmy obecného klidu před zájmy právními i hygienickými stejně jako před ohledy „filantropickými“. Můžeme se jen dohadovat, zda tu mohla hrát roli i vypjatá politická situace - Vídní otřásly jakobínské procesy následované popravami, a právě v roce 1796 ohrožovala francouzská vojska bezprostředně i jižní hranici, k níž přiléhá studované území. Není tedy divu, že každé srocení lidu budilo obavy a neklid.

Nový trestní zákoník Františka I. z roku 1803 transformoval sebevraždu v pouhý policejní přestupek; „usvědčení“ sebevrazi však měli nadále končit mimo hřbitovní půdu, kam je však již měl zakopat soudní posel či hlídka. Dekret z roku 1830 nicméně posílil kompetence chirurgů ohledávajících tyto zemřelé a jejich pravomoci rozhodovat o duševním stavu, a tedy i o posmrtném osudu zemřelých (Liepoldová 2018; 2019; Tinková 2019).

Obavy z „nečistého zemřelého“ však mezi obyvatelstvem přetrvávaly nadále a zakopání takového těla, zejména do posvěcené půdy hřbitova, probouzelo nevoli a úzkost. Ani konsenzus mezi světskými autoritami a „experty“ tak ještě neznamenal konec „vylučování“ sebevrahů z posvěcené půdy. Ani předpokládané a (soudní pitvou) těžce dokázané šílenství

17 SOA Třeboň, pobočka Český Krumlov, VS Český Krumlov sign. II B 5 BC 3, U) (13), př́ípad Martina Hoffmanna, Černá v Pošumaví (Schwarzbach), 1796. 
nutně nesnímalo ze sebevraha poskvrnu "nečistoty“ a zdroje strachu. Odpor poddaných vůči přijetí „nečistého" mrtvého mezi ostatní zemřelé tak v některých lokalitách přetrvával, nezř́ldka s (tichou) podporou duchovního, a někdy musel zasáhnout nejen krajský, ale také nejvyšší zemský úřad - gubernium. Např́íklad ve fondech Moravskoslezského gubernia v Brně se zachovala série pěti takových př́padů z let $1810-1844 .{ }^{18} \mathrm{~S}$ jedinou výjimkou, již představuje Jihlava (a které se zde nebudeme pro její nejednoznačnost a odlišné souvislosti věnovat), přišly všechny ostatní stížnosti z oblasti Slezska a severních částí Moravy. Ostatně také jeden př́pad, který uvádí A. Navrátilová na základě etnografické literatury, se vztahuje k severomoravskému regionu: V Křelově na Olomoucku prý znepokojení sousedé v roce 1840 za noci vykopali na hřbitově pochovaného oběšeného vojáka a sami zahrabali za hranicemi obce a v noci hlídkovali na hřbitově, aby se tam nežádoucí tělo nevrátilo (Navrátilová 2004: 316317). A přesně takové př́klady nacházíme i ve zmíněném fondu nejvyššího zemského úřadu pro moravskoslezskou zemi.

Velmi emotivně vypjatý př́íběh se odehrál na sovineckém panství (Eulenberg) počátkem roku 1810. V obci Veveř́ (Eichhorn) se 30. ledna 1810 oběsila jednapadesátiletá Magdalena Dittrichová. ${ }^{19}$ Vrchnostenský úřad povolil pohřeb na hřbitově, avšak odpor místní komunity byl tak silný, že krajský úřad - kvůli zachování veřejného klidu - změnil „rozsudek“ nižší instance na rozhodnutí uložit tělo zesnulé mimo hřbitovní půdu, navzdory zoufalé př́mluvě jejích dvou bratrů.

Dramatický př́pad „ukradeného těla“ třiašedesátileté výměnkářky Rosiny Krkošky z Koloredova nyní detailně studoval Radek Lipovský, v jehož studii najdeme zevrubný rozbor „aféry“ (Lipovský 2018). Opět šlo o ženu, u níž ve výpovědích panovala shoda, že byla dlouhá léta „,nepř́íčetná“, a měla být pohřbena na „křestanském“ hřbitově, nicméně při pohřbu v Místku došlo ke vzbouření několika stovek lidí, kterému nedokázal zamezit ani vrchnostenský úřad. Houf rozhořčených poddaných dokonce rozehnal pohřební průvod, takže tělo zůstalo ležet na návrší, odkud se jej marně pokusil ras se svou manželkou odvléct na hřbitov do Místku. I tam však došlo ke srocení a z věže hřbitovního kostela dokonce zazněly dva varovné výstřely. Rozlícené ženy zabránily hrobníkovi ve vykopání hrobu a také děkan se omluvil pro údajnou „nemoc“. Jeho pozdější omluva je pro nás také zajímavým průhledem do lidového smýš-

18 MZA Brno, B 14 - Moravské místodržitelství - starší, karton 4537, signatura 112 (Sebevrazi, utopenci 1769-1844). č. j. 5910/401.

19 MZA Brno, B 14 - Moravské místodržitelství - starší, karton 4537, signatura 112 (Sebevrazi, utopenci 1769-1844), č. j. 5910/401, př́ípad Magdaleny Dittrichové (1810). 
lení: lidé mu prý vyhrožovali, že pokud provede řečený pohřeb, nejen že nebudou chodit do kostela, ale nechají se pohřbívat na svých zahradách. Ze hřbitova vynesou kř́ž a budou tam házet jen uhynulý dobytek. Opuštěné tělo tak dál leželo pod širým nebem. Při dalším pokusu o převoz těla za asistence vojenské hlídky narazil průvod na stržený most a byl vystaven spršce kamení. V nastalém zmatku se srocený dav - podle zprávy až dvoutisícový - vozu s rakví zmocnil, rakev roztříštil a mrtvé tělo hodil do narychlo vykopané jámy a zaházel troskami truhly. Až po zásahu krajského hejtmana a za asistence dvou čet kyrysníků bylo tělo následně exhumováno a přeneseno na místecký hřbitov. Šlo opět o výmluvný př́iklad konfliktu různých racionalit, které se v tomto př́padě maximálně vyhrotily.

Mnohem závažnější důvod k odporu měli obyvatelé slezské obce Grodzietz (snad dnešní polský Grodziec u Bialsko-Biała ležící asi dvacet kilometrů severovýchodně od Těšína), kteří měli do posvěcené půdy přijmout dokonce sebevraha „prríčetného“ ${ }^{20}$ Paul Chlebus se oběsil 7. května 1841 poblíž svého domu v obci Grodzietz. Svědecké výpovědi nepřinesly žádné informace o tom, že by svůj čin spáchal ve stavu šílenství. Dokonce po sobě zanechal závět', z jejíchž ustanovení vydedukovaly vyšetřovací orgány, že o sebevraždě přemýšlel a že jednal zcela rozumně, „s plnou schopností rozvahy a záměru“, což sloužilo jako důkaz, že sebevraždu „skutečně spáchal“ („wirklich vollbracht"). Byl tudíž obviněn ze spáchání policejního přestupku ve smyslu $\$ 92$ II. části trestního zákoníku a měl být pochován mimo hřbitov, což velice kvitovalo místní obyvatelstvo, které se k přijetí sebevraha mezi své mrtvé stavělo nanejvýš nepřátelsky. Farář tehdy mrtvého v rychlosti zakopal za hřbitovní zdí.

Chlebusova žena se však s touto nepřiznivou skutečností odmítla smírit a obrátila se na gubernium do Brna. Svou supliku opřela o pitevní protokol, který hovořil o narušených vnitřních orgánech, což Anna Chlebusová reinterpretovala $\mathrm{v}$ tom smyslu, že její muž nemohl spáchat sebevraždu při plném rozumu, jak žádá zákon. A moravskoslezské gubernium skutečně dekretem z 30. července 1841 (č. j. 28562) nařídilo exhumaci Chlebusova těla a jeho uložení na hřbitově, tedy v posvěcené půdě. Exhumace a nový pohřeb se tak měly odehrát čtyři měsíce (!) po smrti - 9. září 1841. Jako exponent spravedlnosti se na místo dostavil kolem poledne těšínský krajský komisař Herzig, který se na místě dozvěděl, že farář je „údajně nemocen, zjevně kvůli této záležitosti“ (ironická formulace pro krajský úřad naznačuje, co si Herzig o farářově „nemoci“ myslel). Když s místním koo-

20 MZA Brno, B 14 - Moravské místodržitelství - starší, karton 4537, signatura 112 (Sebevrazi, utopenci 1769-1844), č. j. 51736/2366, př́pad Paula Chlebuse z Těšínska. 
perátorem, který faráře nahradil, a několika nepř́liš ochotnými grodzieckými úředníky kolem šesté hodiny večerní konečně dorazili ke hřbitovu, už tam čekal poměrně značný shluk lidí. Dav, jehož množství odhadoval Herzig zhruba na sto čtyřicet lidí („převážně žen“), byl však „stále rozběsněnější a divočejšsí. Protože usoudil, že by v př́padě pokusu o exhumaci hrozilo, že by členové komise byli „k smrti ubiti“ (todtgeschlagt), odhodlal se povolat vojáky, kteří zrovna kvartýrovali v Grodzietzi. Ale vojenská př́tomnost shromážděný dav ještě více podráždila, rozzuřila a začaly létat kameny. Herzig nechal přivolat dalších pětačtyřicet vojáků, ale marně: výstražnou střelbu se však použít zdráhal, proto na „další úřední postup" rezignoval. $\mathrm{O}$ dva dny později, vyzbrojen novým pověřovacím dekretem z těšínského krajského úřadu, nechal vojensky hlídat nejagresivnějš́ občany a vyrazil na grodziecký hřbitov v doprovodu nejméně stoosmdesátičlenného vojenského komanda. Exhumace měla proběhnout jedenáctého ve čtyři hodiny odpoledne. Proč nezvolil raději méně nápadný noční čas, kdy se sebevrazi právě s ohledem na rozjitřené veřejné mínění pochovávali často, není jasné. Prostor na hřbitově i před ním byl opět obklopen davem, navzdory nesouhlasnému mručení shromážděného davu se záměr během tř́ hodin realizovat podařilo. Harzig ponechal na místě pro jistotu hlídku o dvou mužích a opodál zůstalo v záloze osmnáct vojáků.

Aféra Paula Chlebuse opět odhaluje několik obecnějších jevů. Na jedné straně přetrvávající zarytý odpor komunity vůči „nečistému“ zemřelému, podporovaný vůlí duchovních, na straně druhé pak demonstrativní osvícenský „filantropismus“ světských orgánů, zde ztělesněný krajským komisařem Herzigem a konečně i postojem vyšších zemských úředníků.

Podobný př́ípad se sebevrahem, jehož „nepříčetnost“ byla více než problematická, se odehrál jen o pár let později také poblíž Králík, kde neprátelský postoj komunity výrazně posílil také odpor místního duchovního. Zde je však nutno upozornit na odlišnost ve zdroji odporu: hlavním iniciátorem odmítnutí zde byl totiž duchovní, nikoli komunita samotných prostých věŕících. Dne 12. února 1844 se v Moravském Karlově (Karlsdorf) na janovickém panství zastřelil v opilosti Josef Beitel (psáno i Beutel či Beütel), pro svou zálibu v kořalce ostatně proslulý. ${ }^{21}$ Zdůvodnění „nepř́íčetnosti“ bylo samozřejmě nezbytné kvůli zproštění viny, ale i kvůli tomu, že rodina si evidentně prála pohřeb na hřbitově. Vrchnostenský úrad souhlasil a povolil tichý pohřeb, specifikovaný jako „ohne Gesang und Glocken“, beze zpěvu a zvonů. To bylo vzápětí sděleno lokálnímu

21 MZA Brno, B 14 - Moravské místodržitelství - starší, karton 4537, signatura 112 (Sebevrazi, utopenci 1769-1844), č. j. 24440/1289 (př́pad Josefa Beitela/ Beila z Moravského Karlova u Králík). 
kaplanovi Thomasi Fuchsovi z Malé Morávky (Klein Mohrau, dnes okr. Bruntál), který měl obřad provést. Jenže duchovní odmítl a odmítl i vykropit mrtvolu. Když se pak na hřbitově sešlo větší množství lidí, mrtvého syna musel na žádost hrobníka do hrobu uložit sám jeho otec. (I toto snad můžeme interpretovat jako projev odporu vůči „nečistému“ mrtvému.) Postoj duchovního každopádně vzbudil nevoli světských autorit. Olomoucký krajský úřad si okamžitě stěžoval na arcibiskupskou konzistoř a požadoval, aby se kaplan Fuchs ze svého jednání zodpovídal a aby dodatečně alespoň vykropil hrob. Konzistoř [arcibiskupem byl tehdy vídeňský rodák kardinál Maxmilián Josef Sommerau-Beckh (1769-1853), v arcibiskupském úřadě v letech 1836-1853)] se však jednoznačně postavila za Fuchse. A oproti tvrzení krajského úřadu namítla, že kaplan se odmítnutím vykropení sebevrahovy mrtvoly nijak neprovinil ani církevním, ani světským předpisům, nebot dotyčný Beitel nevedl řádný život a nedodržoval přikázání. Ani stav opilosti konzistoř pochopitelně nepovažovala za ospravedlňující jednání, které by Beitela zbavovalo obvinění ze sebevraždy. Zkrátka, podle konzistoře naopak pochybil vrchnostenský úřad, když po Fuchsovi takové úkony chtěl, a dodala, že duchovního nemůže nikdo k takovému počinu nutit.

Krajský hejtman, Franz hrabě von Merkandin, nemeškal a obrátil se př́mo na zemskou vládu - moravskoslezské gubernium, jehož prezidentem byl v letech 1834-1845 Alois Ugarte ml. (1784-1845). Obsáhlý protokol prozrazuje, jak dlouhá byla diskuse na guberniu. Lokálnímu kaplanovi bylo následně sděleno, že v tomto př́padě měl jednat $\mathrm{s}$ „nezbytnou shovívavostí a mírností“ (Mässigung und Schonung) a s „křestanskou mírnosti“ (christliche Milde) spojenou s odpovídající „pastorální moudrostí“ (Pastoralklugkeit), což je tím důležitější, že podobné aféry mají „snadno velmi smutné dopady na stav obecného klidu a řádu" (sehr traurige Folgen für die Zustand der öffentlichen Ruhe und Ordnung).

Nastává tak už zcela odlišný „situační model“ než v předosvícenské době: sebevrah spočívá na hřbitově, bezesporu v posvěcené půdě; nedá se tedy ríct, že by jeho pohřeb, byt' „tichý" (přesto u něj asistuje, jak víme, množství lidí!), byl „potupný“. Nejde již o to, zda má, či nemá být dotyčný uložen na hřbitově (navíc u člověka, u něhož byla nepříčetnost více než sporná, stejně jako jeho zbožnost). To, co si sebevrahova rodina nárokuje, je prrítomnost duchovního, a především vykropeni těla a hrobu, čili čistě církevně-katolické úkony, které svou podstatou skutečně náleží pouze do kompetencí katolické církve. „Konfliktní potenciál“ tedy spočívá především v odmítnutí prítomnosti duchovního při pohřbu a vykropení jámy, tedy v ne-provedení křestáansko-katolického úkonu, na který si sebevrahova rodina, podporovaná světskou mocí, činí nárok proti postoji místního 
duchovního podporovaného arcibiskupskou konzistoří. Konflikt tedy nastal kvůli ne zcela přesně vymezenému pojetí „tichého“ pohřbu: Postoj kaplana Fuchse stejně jako argumentace konzistoře je vlastně naprosto legitimní a v souladu s katolickou doktrínou - tím spíše, že o sebevrahově zbožnosti a počestném životě panovaly oprávněné pochybnosti. Rodina tudíž požadovala od duchovního službu, kterou ze svého úřadu a ze své vůle vykonat mohl, ale rozhodně nemusel; naopak jeho odmítavý postoj je v rámci kanonické katolické racionality vlastně pochopitelný.

Na druhé straně snad můžeme zobecnit, že světské úřady - což je nejvíce patrné $\mathrm{z}$ argumentace gubernia - požadují především shovívavost, vstřícnost, vlastně i nadhled a ústupek vůči vlastnímu svědomí a pravidlům. Nevyvolávají konflikt, ani neobviňují duchovní úřady z intolerance: bezpochyby jsou si vědomy skutečnosti, že sebevrahova rodina není tak zcela „v právu“. Přesto intervenují, smírnými slovy, v její prospěch, opět za účelem zachování veřejného klidu.

\section{Závěrečné shrnutí}

Studie se snaží ukázat, do jaké míry hrál ještě ve studovaném období klíčovou roli koncept „nečistoty“, „pošpinění", který zjevně zakládal i legitimitu řady „parajudiciálních“ praktik aplikovaných na těle sebevraha (utínání hlavy a údů, spálení či zakopání objektů, které př̌ǐly do styku se sebevrahovým tělem nebo s jejichž pomocí se dotyčný sprovodil ze světa). Tyto praktiky, zakotvené zpravidla pouze obyčejově, je možné snad interpretovat jako rudimenty odlučovacích či očistných rituálů s prvky ochranné magie, které přetrvaly v některých lokalitách až do 18. století, a to často nezávisle na rozhodnutích světských i církevních soudů. Ani zbavení viny a prohlášení sebezabité/ho za „nepříčetného“ z něj v očích venkovské komunity nesnímalo asociaci s „pošpiněním“. To bylo dokumentováno na otázkách snímání či nesení sebezabitých: Jakkoli byly některé osoby prohlášeny za „nepříčetné“, a tudíž nevinné, jejich těla často nechtěli „počestní“ poddaní odříznout a předměty, s nimiž přišli sebezabití do kontaktu, byly spáleny nebo zakopány s jejich tělem apod. Do této souvislosti jsou pak zasazeny právě i „hřbitovní revolty“, které ukazují, že „lidovéc prostředí skutečně mezi „usvědčeným“ a „osvobozeným“ sebevrahem nerozlišovalo: zakopání do profánní, neposvěcené půdy se setkávalo s odporem jak u sebevrahů „odsouzených“, tak u osob zbavených viny pro duševní poruchu: obavy z nečasu, neúrody či poškození úrody panovaly evidentně u obou a obou vládla představa možných „přízrakư “ či „duchư“. Tento generalizovaný strach lze dát možná do souvislosti se zcela základními potřebami a obavami rurálních komunit, pro něž neú- 
roda či projevy nepřízně počasí typu krup či velkého sucha představovaly události naprosto fatální. Proto byl každý element, který na komunitu mohl takové neštěstí přivolat, zdrojem největšího strachu.

O to větší nevoli pak budilo ukládání do posvěcené půdy hřbitova, která byla tak vnímána, zejména duchovními, ale i př́slušníky venkovské obce, jako znesvěcená. Toto znesvěcení mohlo přivolat i Boží hněv, který se mohl projevit opět i sesláním život ohrožující pohromy. Zvláštní konfliktní potenciál pak nesly př́pady z 19. století, kdy světská moc - zpravidla z hygienických důvodů - již pohřbívání mimo vyhrazená místa odmítala tolerovat a dávala souhlas s pohřby nejen sebevrahů usvědčených, ale i pochybných morálních a religiózních kvalit. Ještě zajímavější konflikt racionalit představují př́pady, kdy se za pohřeb jinak zbožného a nekonfliktního sebevraha přimlouvá sám duchovní, a to navzdory odporu svých farníků. Nebo naopak, kdy světská moc raději souhlasí s vyloučením zemřelé/ho z posvěcené půdy, než by riskovala na svém panství projevy nevole či prímo vzpouru. Nečistá těla v posvátné půdě byla bez ohledu na osobnost zemřelé/ho a výsledky vyšetřování vnímána jako trvalý zdroj ohrožení pro celou komunitu. Chápání znesvěcení, „nečistoty“, pošpinění se tak mohlo v myšlení prostých poddaných zcela míjet s pojetím „oficiálním“, církevním či právním. Jeho logika a s ním spojené „parajudiciální" praktiky a strategie „vyloučení“ či naopak „očisty“ tvořily součást ochranné magie úzce spjaté se základními potřebami rurálních komunit, zejména těch odlehlejších a více ohrožených chudobou.

Protože studie byla založena především na materiálech z jihozápadních Čech s výlučně katolickým obyvatelstvem, nebylo možné provést jistě zajímavé srovnání s postoji u evangelíků (ani v jiných autorkou dosud studovaných regionech nebyli evangeličtí sebevrazi nalezeni).

Duben 2020

\section{Bibliografie}

Prameny rukopisné - nevydané

Moravský zemský archiv (MZA) Brno, B 14 - Moravské místodržitelství - starší, karton 4537, signatura 112 (Sebevrazi, utopenci 1769-1844)

Státní oblastní archiv Třeboň, pobočka Český Krumlov, velkostatek Český Krumlov, signatura I $6 \mathrm{C} \alpha$, fascikly 8 a 9

Státní oblastní archiv Třeboň, pobočka Český Krumlov, fond Ústřední kancelářr, starší oddělení - Postoloprty, Hluboká 
SOA Třeboň, pobočka Český Krumlov, VS Český Krumlov sign. II B 5 BC 3

Sbírka matrik Jihočeského kraje, SOA Třeboň, digitální archiv

Prameny tištěné, pramenné edice

Allgemeines Gesetz über Verbrechen und derselben Bestrafung (česky jako Všeobecný zákoník o zločinech a trestech za ně). 1787. Wien, II. část, Viertes Kapitel. Von Verbrechen, die auf das menschliche Leben und die körperliche Sicherheit unmittelbare Beziehung haben (\$\$ 89-125).

Augustinus Aurelius. Ed. 1979. De Civitate Dei / Der Gottesstaat. I. díl, kniha I-XIV, překlad a edice Carl Johann Perl. Paderborn - München - Wien - Zürich: Ferdinand Schöningh.

Černá kniha Velké Bíteše. 1979. Verbík, Antonín - Štarha, Ivan (eds.). Brno: Blok.

Gesetzbuch über Verbrechen und schwere Polizei-Uibertretungen. 1803. Prag: In der von Schönfeldschen k. k. Hofbuchdruckerey, 326 s. Druhý díl věnovaný policejním přestupkům: Gesetzbuch über schwere PolizeyUibertretungen. 1803. Prag: In der von Schönfeldschen k. k. Hofbuchdruckerey, $216 \mathrm{~s}$.

Kniha práw nad prě̌iněnjmi hrdelnjmi a těžkými řádu Městského, (totiž Policye) přestupky. 1804. Díl I., II., Vídeň, J. T. Grozný z Trattnerůw. Zedler, Johann Heinrich. 1721. Grosses vollständiges Universal-Lexicon aller Wissenschafften und Künste. 1721-. Halle - Leipzig, t. 36, p. 1595, Vº Selbstmord.

\section{Sekundární literatura}

Červeňanská, Ňuta. 1973. Prvé obdobie vývoja resuscitácie. Bratislava: Vydavatel'stvo Slovenskej akadémie vied.

Dülmen, Richard van. 2003. Bezectní lidé. O katech, děvkách a mlynářích. Nepočestnost a sociální izolace v raném novověku. Praha: Dokořán.

Frank, Michael. 1994. Die Fehlende Geduld Hiobs. Suizid und Gesellschaft in der Grafschaft Lippe (1600-1800). In: Signori, Gabriela (ed.): Trauer, Verzweiflung und Anfechtung. Selbstmord und Selbstmorderversuche in mittelalterlichen und frühneuzeitlichen Gesellschaften. Tübingen: Edition Diskord: 152-188.

Van Gennep, Arnold. 1997. Přechodové rituály: systematické studium rituáli. Praha: NLN.

Grubhoffer, Václav. 2018. Zdánlivá smrt. Noční mưra osvícenské Evropy. Polička: Městská knihovna. 
Houston, Robert Allan. 2010. Punishing the Dead? Suicide, Lordship, and Community in Britain, 1500-1800. Oxford: Oxford University Press.

Kästner, Alexander. 2011. Tödtliche Geschichte(n). Selbsttötungen in Kursachsen im Spannungsfeld von Normen und Praktiken (1547-1815).

Konflikte und Kultur - Historische Perspektiven Band 24. Konstanz: UVK Verlagsgesellschaft mbH.

Koslofsky, Craig. 1997. Von der Schande zur Ehre. Nächtliche Begräbnisse im lutherischen Deutschland (1650-1700). Historische Anthropologie 5, 3: 350-369.

Koslofsky, Craig. 1999. Säkularisierung und der Umgang mit der Leiche des Selbstmörders im frühmodernen Leipzig. In: Lehman, Hartmut Trepp, Anne-Charlotte (edd.): Im Zeichen der Krise. Religiosität im Europa des 17. Jahrhunderts. Göttingen: Vandenhoeck \& Ruprecht 387-404.

Koslofsky, Craig. 2004. Controlling the Body of the suicide in Saxony. In: Watt, Jeffrey R. (ed.): From Sin to Insanity. Suicide in Early Modern Europe. New York: Cornell University Press 48-63.

Koštál, Josef. 1914. Hlína ze hřbitova. Český lid XXIII: 269.

Lederer, David. 1994. Aufruhr auf dem Friedhof. Pfarrer, Gemeinde und Selbstmord im frühneuzeitlichen Bayern. In: Signori, Gabriela (ed.): Trauer, Verzweiflung und Anfechtung. Selbstmord und Selbstmorderversuche in mittelalterlichen und frühneuzeitlichen Gesellschaften. Tübingen: Edition Diskord: 189-209.

Liepoldová, Tereza. 2018. Mrtvoly a ohledači. Případ faráře Hayneho a vyšetřování sebevražd na Litoměřicku v 1. polovině 19. století. Cornova 8, 2: 83-101.

Liepoldová, Tereza. 2019. Právo a medicína ve vztahu k mrtvým tělům (sebevrahů) na přelomu 18. a 19. století. Historie - Otázky - Problémy 11, 1: 164-176.

Lind, Vera. 1999. Selbstmord in der frühen Neuzeit. Göttingen: Vanderhoeck - Ruprecht.

Lipovský, Radek. 2018. Ukradené tělo. Vlastivědný věstník moravský LXX, 2: 146-167.

Luef, Evelyne. 2010. ... boshaftig den entsetzlichen selbstmord angethann. Selbsttötung als strafrechtliches Delikt im frühneuzeitlichen Österreich. In: Griesebner, Andrea - Tschannett, Georg (edd.): Ermitteln, Fahnden und Strafen. Kriminalitätschistorische Studien vom 16. bis um 19. Jahrhundert. Wien: Löcker Verlag: 165-190.

Luef, Evelyne. 2016. A Matter of Life and Death: Suicide in Early Modern Austria and Sweden (1650-1750). Dissert. Wien: rkp.

MacDonald, Michael - Murphy, Terence R. 1990. Sleepless Souls: Suicide in Early Modern England. London: Clarendon Press. 
Malý, Tomáš. 2018. Otázka sebevraždy v teologických a morálněfilosofických textech 18. století: př́klad habsburské monarchie. Cornova 8,2 : 51-66.

Murray, Alexander. 2009. Suicide in the Middle-Ages vol. I, II. Oxford New York: Oxford University Press.

Navrátilová, Alexandra. 1996. „Nečistí zemřelí" v posmrtných a pohřebních obřadech českého lidu. Český lid 83: 21-31.

Navrátilová, Alexandra. 2004. Narození a smrt v české lidové kultuře. Praha: Vyšehrad.

Otto, Rudolf. 1917. Das Heilige: Über das Irrationale in der Idee des Göttlichen und sein Verhältnis zum Rationalen. Breslau: Trewendt \& Granier.

Pátková, Hana. 2014. Několik poznámek k okolnostem smrti Jakuba Jana Ryby. Podbrdsko: sborník Státního okresního archivu v Př́ibrami 21: 95-103.

Schär, Markus. 1985. Seelennöte der Untertanen. Selbstmord, Melancholie und Religion im Alten Zürich, 1500-1800. Zürich: Chronos.

Schmidt-Kohberg, Karin. 2003. ...und hat „sich selbsten ... an ein Strickhalfter hingehenckt ..." Selbstmord im Herzogtum Württemberg im 17. und 18. Jahrhundert. In: Dillinger, Johannes (ed.): Zauberer Selbstmörder - Schatzsucher. Magische Kultur und behördliche Kontrolle im frühneuzeitlichen Württemberg. Trier: Kliomedia: 113-220.

Spierenburg, Pieter. 1984. The Spectacle of Suffering: Executions and the Evolution of Repression; From a Preindustrial Metropolis to the European Experience. New York: Cambridge University Press.

Sumner, William Graham. 1906. Folkways. A Study of the Sociological Importance of Usages, Manners, Customs, Mores and Morals. Boston: Ginn and comp.

Svobodová, Martina. 1995. Smolná kniha soudní města Chrastary (15651770). Diplomová práce. Liberec: Technická univerzita v Liberci.

Šimeček, Josef. 1912. Pohřeb oběšence na začátku věku XIX. Český lid XXI: 184-190.

Tinková, Daniela. 2004. Hř́ch, zločin, šílenství v čase odkouzlování svèta. Praha: Argo.

Tinková, Daniela. 2012. Zákeřná Mefitis. Zdravotní policie a veřejná hygiena v pozdně osvícenských Čechách. Praha: Argo.

Tinková, Daniela. 2018a. Temná zákoutí mysli. In: Hojda, Zdeněk Ottlová, Marta - Prahl, Roman (eds.): Svètlo, stíny a tma v české kultuře 19. století. Sborník př́spěvků z 37. ročníku mezioborového sympozia k problematice 19. století. Praha: Academia: 93-112.

Tinková, Daniela. 2018b. Selbstmordstrieb auf den Leib eingeschrieben. Selbsttötungsdebatte in der französischen und deutschen medizini- 
schen Literatur an der Wende des 18. und 19. Jahrhundert. In: Brünner Beiträge zur Germanistik und Nordistik 32. Supplementum: Literatur und Suizid. Brno: 11-33. Dostupné z: https://digilib.phil.muni.cz/bitstream/handle/11222.digilib/138926/1_BrunnerBeitratgeGermanistikNordistik_32-2018-3_4.pdf? sequence=1

Tinková, Daniela. 2019. Bez zpěvu a bez zvonění. Tělo a duše sebevraha před vrchnostenskými soudy v předosvícenském období. Historie otázky - problémy 11, 1: 146-165. Dostupné z: https://historieotazkyproblemy.ff.cuni.cz/

Vandekerckhove, Lieven. 2001. On Punishment: The Confrontation of Suicide in Old Europe (Samenleving, Criminaliteit en Strafrechtspleging). Leuven: Leuven University Press.

Watt, Jeffrey R. 2001. Choosing Death: Suicide and Calvinism in Early Modern Geneva. Kirksville: Truman State University. 